\title{
The Living Institutions of the EU: Analysing Governance as Performance
}

\author{
MAARTEN A. HAJER \\ Department of Political Science, University of Amsterdam, Amsterdam, The Netherlands
}

\begin{abstract}
How to analyse the dynamics of informal governance that takes place in networks that are multi-party, polycentric, trans-national and - almost by necessity - inter-cultural? This paper portrays informal governance in the EU as a complex game of negotiation. Actors not only negotiate outcomes but also the rules according to which the negotiation is to take place. This process creates 'living institutions' in which participants agree upon rules and credibility and authority for its joint decisions gets established. The argument of the paper is that this implies a crucial role for the dramaturgy of negotiation that co-determines if a negotiation is successful or not. The paper suggests governance should be approached as a sequence of staged performances.
\end{abstract}

KEY WORDS: Informal governance, institutional ambiguity, democratic legitimacy, dramaturgical analysis, discourse analysis

Impressed with command, we see little else.

(Geertz, 1980)

\section{The Symbolic Side of Informal Governance}

Although it is often forgotten, governance crucially depends on symbols. Think of the falling hammer that marks a decision: even in the most routinized forms of government symbolic acts play a crucial role. If we notice this symbolic dimension it often seems to be regarded as merely a superficial, ceremonial topping of the core business of governance. But could it help us to understand the dynamics of the policy process? Could it help us to get our finger behind the way in which power is exercised?

Over-looking the symbolic often stems from the fact that we have grown accustomed to symbolic references; we simply take them for granted. It is no surprise therefore that precisely those who are new to a situation, or those who are confronted with the power infested in symbolic gestures and rituals, are very aware of them. Surely this is an element of power too: not knowing the symbolic order gets expressed in acting 'clumsy', and this subsequently affects the power position in negotiations. But symbolic politics is present in daily policy making too. It gets 
expressed in narratives of people reflecting on their experiences in governance. Take this comment of a member of the European Parliament, representing the Parliament's environmental committee in the negotiations about a trans-European transport network.

The worst meeting was the second formal meeting... which was held in the new Council of Ministers building across the road from the Parliament, which is a huge power building, a megalopolis, designed by Stalin and built by Mussolini. It's the most incredible big heavy granite and marble edifice with huge ceilings. And we kind of crept in looking like worms, and we were put in this enormous room with a big table half a mile long... and it was just intimidation, total intimidation. (Jensen \& Richardson, 2004, p. 131)

Evidently, the symbolic played a role in this negotiation: the very decision to meet at this location was perceived and interpreted as an intimidation by this Member of the European Parliament. What is more, perhaps the meeting was even scripted and staged: in that case the choice of the location was consciously mobilized to have an affect on the negotiation. In this case to understand the negotiation requires us to pay attention to this symbolic dimension.

Scholarship on the symbolic dimension of state power is strong but scarce (e.g. Edelman, 1964; Goodsell, 1988). Recently there has been a resurgence of this type of work and perhaps the debate on the dynamics of formal and informal governance in the European Union might profit from this scholarship. Mak and van Tatenhove (2006 this issue) define informal practices of governance as those non-codified settings of day-to-day interaction concerning policy issues, in which the participation of actors, the formation of coalitions, the processes of agenda setting and (preliminary) decision making are not structured by pre-given sets of rules or formal institutions. This raises the question how such rules are worked out in those instable practices. What lends these coalitions stability, and when are they able to generate meaningful public policies?

All policy making depends on rules and routines. If we would not have rules and routines policy makers would lose themselves in endless misunderstandings, reiterations and constant quests for conformation. Rules and routines help avoid or help transform conflicts, generate trust and guide expectations. Many rules and routines are written into 'constitutions' of various sorts (from agreed-upon standard operating procedures to formal constitutions defining the power of key institutions). But in informal governance such constitutions do not, by definition, stipulate any rules. Informal governance operates, in this sense, in the shadow of the law. This raises an important question: How are agreements reached in such informal settings?

Politics, whether formal or informal, is always a symbolic order. Yet attending to the symbolic might be particularly useful for understanding settings of informal governance. We can study this symbolic dimension as it surfaces for instance in the language being spoken, in the objects being used and in rituals being performed. Paying attention to the symbolic thus helps us understand how authority is created and maintained, how power is exercised, how power differentials are maintained, and how understandings of the limitations and possibilities of a new democratic politics might take shape (cf. Gagliardi, 1990; Yanow, 1996). 
The recent work on 'performance' takes a new step that can be usefully employed to understand processes of informal governance. It suggests that politics constantly needs to be enacted, and that the political process can be analysed as a multiplicity of staged performances (Hajer, 2005; Hariman, 1995; Hilgartner, 2001; Szerszynski et al., 2003).

\section{Conditions for Governance}

In order to get a handle on the dynamics of European governance it might be helpful to first conceptualize the conditions for governance, i.e. the situation in which policy makers have to operate. Their reality is one of problem solving in a multi-level context in which concerted action requires people to act on different levels of governance, often without the possibility to order actors operating on other planes of government around. Policy making then is a negotiation in a networked and multiparty settings, with players from a widely diverse background, that come at the situation not necessarily sharing the same 'frame'.

In such a multi-level setting governance is absolutely not a routine-like activity. We might capture the particular complexity using two concepts: institutional ambiguity and multi-signification. First of all, institutional ambiguity (Hajer, 2003; Hajer \& Wagenaar, 2003) ${ }^{1}$ refers to the fact that, more than before, solutions for pressing problems cannot be found within the boundaries of sovereign polities. Established institutions often lack the powers to deliver the required or requested policy results on their own. They therefore have to interact in (1) multi-party, (2) polycentric (and often trans-national) and, almost by necessity, (3) inter-cultural networks of governance. ${ }^{2}$ This is obviously the case for many policy processes in the European Union. In this context, a shared notion of the 'rules of the game' cannot be assumed and agreements on the rules of the game thus have to be worked out in the process.

Institutional ambiguity is a situation in which there is no single 'constitution' that pre-determines where and how a legitimate decision is to be taken. Actors bring their own assumptions about rules and authority. Consequently, the policy process itself becomes the site at which rules need to be negotiated. An extreme case of institutional ambiguity is one where there is no obvious starting point and shared rules have to be built up from scratch, as for example during the establishment of the European Coal and Steel Community (cf. Rittberger, 2001). This extreme case I suggest to call a situation of institutional void.

Secondly, there is the phenomenon of multi-signification. Human beings are meaning-making animals and to make sense of what happens around us, to make sense of the 'significance' of a particular event, we draw, implicitly or explicitly, on systems of signification (cf. Hajer \& Laws, 2006). However, as the respective participants in a policy deliberation operate from distinct system of signification, the very meanings that are at stake for the various participants are often unclear to each other. Multi-signification is a broad challenge to contemporary politics: different ethnic communities, different life styles, and distinct ideological or religious convictions all relate to particular discourses or systems of signification.

In policy making conflicts of meaning and misunderstandings abound. More often than not, we do not know much about the 'estate', the relative ranking of 
participants, their mutual understanding of their status, what is at stake for others, and to what extent claims are negotiable in current settings. Consequently, this too has to be worked out in the policy process. As an extra complication for the European context, Trondal and Veggeland (2003) have pointed to the importance of representational ambiguity. ${ }^{3}$ Representatives have to enact a partially conflicting role set, as they are exposed to contending expectations from different institutions, both from the EU and from the national level (Trondal \& Veggeland, 2003, p. 63). This makes it extra difficult to discern who the representatives are and whom they represent. Indeed, many informal practices seem to have been set up in order to have a safe setting in which to clarify the signifying patterns that actors bring to a policy negotiation.

Institutional ambiguity and multi-signification constitute fundamental challenges to the process of European governance. Parties have to work out a mutual understanding of the relevant signifiers and rules of the game. In good analytical spirit one might think this is what actors do before they start a negotiation. But this would be an academic projection of our own inclinations on the real world of politics. In actual fact, institutional ambiguity and multi-signification are not such mild conditions that all differences can be discussed in the round. Instead we see how actors negotiate rules in an ongoing policy-oriented practice (Hajer, 2003). Analytically, we are left with the task to unpack the exchanges for the various layers of negotiated meaning that takes place. On this Frank Fischer has come up with helpful and widely employed heuristics (Fischer, 1980, 2003), but his scheme is different in analytical orientation from the one I am promoting here. Rather than examining purely the content of the exchange on different levels, I suggest ways to get at the mechanisms that determine the dynamics and try to relate the discursive to the analysis of the setting of the policy interaction. People do things with words but settings do things with words and people too - as becomes all too clear in the example with which this article started. A discussion is not merely talk; it is an act as well. And every act takes place in a particular 'contexture' (Lynch, 1991) that influences the quality of the act.

The significance of this approach lies in the fact that it brings institutions to life. The EU is often discussed in terms of its legal-institutional arrangements. Much less attention has been paid to the way in which these formal organizational charts are turned into living institutions, with their own informal practices and specific rules for appropriate behaviour in specific types of situation (Olsen, 2000). This is what the analysis of politics as performance could achieve. If the political process is analysed as sequence of staged performances, informal governance is a constant negotiation of the rules of the game and an attempt to compromise the unclear systems of signification towards a mutually agreeable policy text.

European governance is full of cases in which effective political action needs to be defined in a situation for which there are no generally accepted rules and norms according to which policy conflicts are to be resolved. This applies for instance to the European committee system, or, as Everson and Joerges (2000, p. 183) put this:

the process of negotiation and opinion-forming within comitology certainly takes national positions into account, but does not fit within current conceptualizations of intergovernmental action; the discussions and debates 
in the committees document involve such an intensive interweaving of interests and arguments that it would be hopeless and artificial to attribute them to individual states or companies; putting that positively, they document the emergence of a, however rudimentary, European polity.

Rather than trying to make sense of such processes in terms of actors only, I would like to invoke the language of 'practice' in which we would focus on the qualities of this interaction.

Finally, for an assessment of informal governance it is important to be able to judge how issues of legitimacy and accountability are handled in such contexts, how the quality of the policy deliberation can be guaranteed and, more basic, how people can come to agree upon what 'really' is at stake. Hence, the more unclear issues of authority and institutionalized routines become, the more important it is to understand politics as performance and to appreciate the 'poetics of power' (Geertz, 1980).

\section{Living Institutions: Discourse, Dramaturgy and Deliberation}

To analyse political processes where the division of roles is unclear (institutional ambiguity) and where there is no pre-given accepted system to differentiate among claims (multi-signification) actors will have to work out, interactively, the rules of the game. Where this works one might speak of 'living institutions' in the sense that the mutually agreed-upon and recognized codes of conduct are the product 'in vivo' negotiations. Informal governance is an expression of this. In order to analyse how such forms of governance work, I suggest using a three-dimensional analytical model consisting of the dimensions of discourse, dramaturgy and deliberation. This model (see Table 1) evolved out of earlier work that paid most attention to the way in which discourses shape up in politics (Hajer, 1995).

Table 1. The discursive dimension of policy analysis

\section{Discourse}

Refers to structures and patterns in a discussion.

'What if our language does not simply mirror or picture the world but instead profoundly shapes our view of it in the first place? (Fischer \& Forester, 1993)

- Discourse: an ensemble of ideas, concepts and categorizations through which meaning is allocated to social and physical phenomena, and which is produced and reproduces in an identifiable set of practices.

- Metaphor: understanding and experiencing a particular thing/event in terms of another.

- Story line: a condensed sort of narrative that connects different discourses and thus provides the basis of 'discourse coalitions'.

- Discourse coalition: the ensemble of particular story lines, the actors that employ them and the practices through which the discourse involved exert their power.

- Practice: operational routines - mutually accepted rules and norms that give coherence to social life.

- Discursive affinity: arguments that may have very different roots and meanings but that together uphold a particular way of seeing.

- Emblematic issue: a specific policy problem that captures the imagination at a particular moment in time and fulfils a key role in the general understanding of a much larger problem complex (metonym).

Note: Concepts as presented and elaborated in Hajer (1995). 


\section{Discourse}

The discourse-analytical approach has been employed to analyse European governance, most notably by Vivian Schmidt (2002) and, more recently, Howarth and Torfing (2004) and Walters and Haahr (2005). In the discourse-analytical tradition much emphasis is given to the way in which conceptions of reality, but also aspirations and irritations, derive from discursive exchanges. Drawing on the tradition of discursive psychology (e.g. Harré \& Gillett, 1994), my approach provides the tools to see how discourses can gain in importance or, indeed, falter to structure politics. Discourse is then understood as an ensemble of ideas, concepts and categorizations through which meaning is allocated to social and physical phenomena, and that is produced and reproduces in an identifiable set of practices.

The recognition of the importance of language as 'systems of signification' in policy and politics has given rise to a rich and varied literature ranging from narrative analysis to discourse analysis, from the study of the role of metaphor to the study of reframing (e.g. Hajer \& Wagenaar, 2003; Roe, 1994; Schön \& Rein, 1994; White, 1999; Yanow, 1995). My own discourse-analytical model is meant to illuminate given structures and patterns in particular policy discussions.

Ultimately going back to the original Wittgensteinian idea of 'language game' the work in the 'argumentative' tradition is well aware of the fact that language does not simply 'float' in society but should be related to particular 'practices' in which it is employed (Fischer \& Forester, 1993; Forester, 1999). In my own work I sought to link discourse analysis to practices as operational routines - mutually accepted rules and norms that give coherence to social life and to discourse coalitions as the ensemble of a particular discourse, the actors that employ it and the practices through which a discourse exerts its power.

Concretely we could try to see how practices of informal governance are in reality governed by existing discourse-coalitions in which they function, whereby discoursecoalitions are made up of a the ensemble of particular story lines, the actors that employ them and the practices through which the discourse involved exert their power. This discourse dimension is summarized in Table 1.

\section{Dramaturgy}

A problem with much work on discourse is, however, that it is too much focused on language, whereas linguistic analysis should ideally be related to the analysis of the practices in which a particular language or languages is/are employed. A second analytical dimension of informal governance would focus on the dramaturgy or theatrical dimension of such practices. It is here that the term 'performance' enters the discussion. If seen from a dramaturgical point of view politics is a sequence of staged events in which actors interactively decide on how to move on.

Performance, of course, is not a new notion for social science research. In his How to Do Things with Words? Austin (1962) pointed at the performative dimension of language: to say something can be an act. Exploring the interconnections between the philosophy of language and the social sciences Austin proposed the term 'performatives' for utterances that imply an action and analysed that, in order for 
speech acts to go well, they must meet certain criteria. These conditions for what Austin called 'happy performatives' (p. 12). Austin noted these conditions for acts that go well in schematic form (pp. 14-15; Table 2).

Looking at these conditions one is struck by the central role of convention, permanence and replication. There is, in others words, a clear sense of a shared repertoire or register of occasions in terms of which an utterance can and is to be understood.

Yet as informal governance has to deal with institutional ambiguity the Austinian approach does not hold as it assumes too many conventions. Pointing this out, David Laws (2001) takes the example of a policy conflict over waste dumps with participants from different municipalities, with business parties and amenity groups involved. A meeting is called to discuss what action should be taken and by whom. Participants to the meeting will inevitably ask themselves 'What sort of occasion is this?', and 'According to which conventions will this meeting be conducted?' Yet perhaps an answer to the question cannot be found in the register of political practices known to them. Or, more precisely, different actors most likely will understand the practice in terms of their own register. Intrigued by the functioning of contemporary 'deliberative institutions' Laws suggests that today's participants may often be struggling with a corollary to the conditions that Austin saw as key to 'happy performatives'.

What is the 'accepted conventional procedure having a certain conventional effect' in which I am participating? or 'What convention do I feel is appropriate?'

What do 'particular persons and circumstances' suggest about the conventional procedure that is being invoked? Do they fit with my ideas of what an appropriate procedure would be?

What procedure are we executing? Do we agree? Do we know how to do it? Is it appropriate?

What conventions are suggested by the actions of other participants? How do they match with my sense of what would be required by the conventional procedure I believe is appropriate?

What rules of conduct are we acting on or should we adopt? (Laws, 2001, p. 6)

Table 2. The Austinian conditions for a happy performative

(A. 1) There must exist an accepted conventional procedure having a certain conventional effect, that procedure to include the uttering of certain words by certain persons in certain circumstances, and further,

(A. 2) The particular persons and circumstances in a given case must be appropriate for the invocations of the particular procedure invoked.

(B. 1) The procedure must be executed by all participants both correctly and

(B. 2) Completely.

(T. 1) Where, as often, the procedure is designed for use by persons having certain thoughts or feelings, or for the inauguration of certain consequential conduct on the part of any participant, then a person participating in and so invoking the procedure must in fact have those thoughts or feelings, and the participants must intend so to conduct themselves, and further,

(T. 2) Must actually so conduct themselves subsequently (Austin, 1962: 14-15). 
So, whereas Austin suggested that speech acts perform by referring back to conventions familiar to us all, Laws suggest that in the unsettling situations of today's multi-party deliberative institutions people first need to agree on a provisional sense on what convention(s) are to prevail.

In both cases the conceptualization of speech acts concerns ways in which people inter-subjectively negotiate a situation. In both cases the notion of 'performativity' occupies central role. In Austin performativity comes out in the idea 'that language does something'. While the work of Wittgenstein and Austin made clear that a discussion is not merely a matter of talk but is a set of acts as well, the question still is how to analyse the interaction and how to account for the influence of the 'setting' in which that interaction takes place.

In discourse analysis the idea is that discourse and practices 'co-construct' participants and their conflicts. Methodologically the discourse-analytical perspective can be enriched if it is combined with an analysis of the dramaturgical dimension of interaction. Invoking dramaturgical terms such as 'performativity' and 'performance' actually opens up a dimension to policy analysis that we could not capture with the discourse-analytical tools alone. The dramaturgical terms convey the understanding that certain meanings constantly have to be reproduced, that signification must be enacted, and that this takes place in a particular 'setting'.

Partly the reproduction of meaning is a matter of quasi-ritualistic acts, repetition that help keeps up institutions, also in policy and politics. But while some performances are about replication, others, in particular in informal governance, are about improvisation (Waterton, 2003); about the way in which an instable situation can be steadied out. In such situations policy processes will be 'staged' differently, with different 'scripts' worked out to achieve a particular result, although in the real-life theatre of politics it always remains to be seen if the performance will be acted out according to the script that the various directors (sic) might have had in mind.

Performance theory explores the ways in which social processes can be understood in dramaturgical terms (Hilgartner, 2001; Schechner, 1988, 1993; Szerszynski et al., 2003). Applying it to European governance would suggest that governance should be regarded as a matter of mutual creation; should be conceived of as a matter of making something, e.g. through constituting particular working routines or, in some cases, the creation of particular "communities of (shared) practice' (Wenger, 1998).

Analysing policy and politics as performance can help to understand politics and policy making in today's world. Performing not only co-determines which rules are followed in the process, it also co-determines which definition of reality is followed, what temporal-spatial frame is seen as 'appropriate', and what constitutes legitimate intervention. Of course, performance has always been a dimension of politics (cf. Edelman, 1964). Yet my point here is that in situations of institutional ambiguity, in which there is an absence of clear and generally accepted rules and norms, the performative can become a dominant force.

In situations of institutional ambiguity, performances that are merely about replication cannot help create new shared understandings with other parties. A frequent finding in such situations is that people tell stories: stories of experience, 
stories of expertise, stories of governance. These stories structure the performance of actors under conditions of institutional ambiguity and multi-signification. This should not surprise us as narratives that have the capacity to be 'read' and understood by different audiences can help convey meaning of the boundaries of particular institutional backgrounds. So in story telling we actually have a practice that performs politics in an ambivalent situation.

Sensitive issues here pose additional challenges. In the case of European food safety policies after BSE, for instance, an exchange of arguments could not take place in a context of shared norms or a priori mutual trust. At the time the Commission intervened as the British claimed to have everything under control while European consumers clearly backed away from British beef. British science and British regulation was mistrusted, in particular, of course because they had claimed for years that there was no risk for human health involved. Surely, shared norms existed but then on the level of particular interpretive communities, such as the families of victims, the particular national food safety authorities (be it that these are deeply disagreeing among themselves), and the environmentalist activists. Yet when such groups met or clashed the exchange itself got a double meaning: the argumentative interplay was intertwined ('what to do') with the renegotiation of trust ('who can be entrusted with the power to control'). In such cases it is the performance that inter-links these two dimensions: the exchange of arguments relies on a particular 'convention' of interacting. If there is no shared convention of rules and norms, the actors first need to 'set the stage' and work out a script for resolving conflict. Secondly, given the fact that there are no pre-given rules to determine the legitimacy of a decision, it becomes important to perform in such a way that people not only trust the players but also trust the procedure and the way in which possibilities for accountability are created. This too seems key to resolving conflicts in a sustainable manner.

This understanding of politics as performance recovers a sense of politics as an artistic endeavour. Politics is an art, and the analysis of politics as performance brings out the skilful way of persuading, the way in which different audiences are 'acted upon', are each approached in an manner appropriate to convincing the group, etc. Trust is the result of performance too. The analytical tools are summarized in Table 3.

Table 3. The dramaturgical dimension of policy analysis

\section{Dramaturgy}

Refers to the physical-symbolical contexture of a discussion.

'Although every act takes place in a setting, we ordinarily take scenes for granted, focusing our attention on actions.' (Edelmann, 1964)

- Scripting: those efforts to create a setting by determining the characters in the play ('Dramatis Personae') and to provide cues for appropriate behaviour.

- Staging: the deliberate organization of an interaction, drawing on existing symbols and the invention of new ones, as well as to the distinction between active players and (presumably passive) audiences.

- Setting: the physical situation in which the interaction takes place, including the artefacts that are brought to the situation.

- Performance: the way in which the contextualized interaction itself produces social realities such as understandings of the problem at hand, knowledge, new power relations and trust. 


\section{Deliberation}

Finally there is the deliberative dimension to informal governance. As informal governance is by definition not governed by constitutional rules, it always runs the risk of being criticized for its legitimacy deficit, or worse, to be characterized as a threat to democratic legitimacy. The prime case of this in European governance seems to be the practices of the 'comitology committees' that play an indispensable role for European governance, whereas their role is constitutionally unclear and the procedures of interaction ('rules of engagement') are often worked out on a very decentralized level. This has not passed unnoticed to policy practitioners and EU theorists (Wessels, 1998). To get a better grasp of the nature of informal governance, one would need to know more about the ways in which the actors engaged in particular practices have developed a mode of operating that sets rules to their interaction. 4

My suggestion here is to include the normative dimension into the analysis of practices of informal governance. I suggest employing a threefold operationalization from the Lasswellian policy science of democracy differentiating between process, knowledge and learning. On the process dimension I suggest borrowing from the booming literature on 'deliberative democracy' some of its key criteria for a good process: reciprocity, inclusiveness, openness, integrity and accountability (Bohman, 1996, 1997; Gutmann \& Thompson, 1996). It might be counter-intuitive to use these criteria for an analysis of informal governance networks. After all, informal networks are often impermeable for outsiders and not controlled by any democratic mechanisms; they seem prone to fail the deliberative test. However, as was made clear in the position paper, it would be a mistake to treat all practices of informal governance alike.

If the point of a proper deliberation is to stage a collective exchange that allows people to transform pre-given opinions into new 'preferences' on the basis of the exchange (cf. Benhabib, 1996), then it is essential to see how knowledge is approached. In the familiar metaphor of Wildavsky (speaking truth to power) knowledge was still conceived of as a product, something that one could 'deliver' (most likely in terms of a report) to a principal. Deliberative policy analysis suggests this take on knowledge is misguided. Knowledge is a product of practice and it is through an extended engagement that viable and sustainable 'knowledge claims' are produced.

Here the recent work in the Science and Technology Studies (STS) is important. This literature has come up with ample examples of how knowledge production is also a performance (Jasanoff, 1990; Latour, 1987, 1994). Similarly, Doug Torgerson (2002) has pointed out that it would be wrong to pit politics as performance against a technocratic approach. That might be tempting, as the objectivist, rigorous, scientist way of conducting policy making seems the antithesis of a performance. Yet as Torgerson points out, the denial of a performative dimension might as well be regarded as a type of performance itself. 'Cost benefit analysis' with its characteristic 'trust in numbers' (Porter, 1995), the variety of 'impact assessments' and the way they are employed in the policy process, the necessity of reductionism and indeed the creation of 'authoritative data', are particular performances, creating a style of operating which can be analysed as a practice of knowledge production, and which is also a way to try and control an ambivalent situation. 
This also links to the learning in policy making. In light of the commitment to facilitate a democratic policy process one needs to think of alternative ways of generating knowledge in the decision making process. The refutation of a suggested differentiation between the playful performative on the one side and the objective technocratic ('science for policy') on the other, leads Torgerson (2002) to wonder how differentiation might help us understand the difference between the technocratic and the more open process. Reflecting on the work of Michael Bakhtin, Torgerson comes up with the differentiation between the posture of the 'monologue' that is characteristic of a technocratic approach and which can be separated from the 'dialogical' performance. Dialogue fits a deliberative mode and can be integrated in the evaluative scheme. It is also an alternative model of knowledge generation. A dialogical model requires a degree of iteration, the attempt to develop plans by taking into account many possible suggestions and critiques. Instead of focusing on knowledge it then makes sense to focus on the adaptive, learning capacities of practices. So, if one takes the BSE crisis in Europe as an example, the monological model is one in which the expert-scientist is called upon to 'speak truth to power', whereas the dialogical model would of course still insist on good scientific, evidencebased input, but would make sure this knowledge was also combined with all the relevant facts to emerge from those actually working in the food chain. As will be remembered, in the BSE case it was not so much the science that was wrong; the problem was that too many unrealistic assumptions were made about how professionals in the slaughterhouses could avoid contamination. A dialogical model would have brought out the fact that certain assumptions were not realistic (see Table 4).

\section{Analysing Informal Practices of Governance}

Informal governance is a key component of European politics as of any other system of governance. European politics is currently particularly interesting as it is struggling to find and define new shared rules for governance. The historically rooted political-cultural diversity of the countries that make up the European polity guarantees years and decades of deliberation under conditions of institutional ambiguity and multi-signification. This paper suggests that this changes the nature of

Table 4. The deliberative dimension of policy analysis

\section{Deliberation}

Refers to the democratic quality of a discussion.

- Reciprocity: discussions must be conducted through an argumentative exchange, hearing both sides, and responding to one another's arguments.

- Inclusiveness: debates require that 'stakeholders' are made part of the argumentative exchange, and that everyone with a stake can have his or her say.

- Openness: the way in which the debate is staged and conducted must avoid unnecessary barriers, including that of (professional) language.

- Integrity: the debate requires honesty and no double play.

- Accountability: those involved are accountable to political bodies and to the public at large, also with regards to the degree to which the rules as laid out have been guaranteed.

- Dialogue: learning through an iterative process in which knowledge is mobilized and enriched through confrontation with a variety of stakeholders and experts. 
what policy deliberation is about. It is not only about policy content and output, it is about the rules of the game and the development of new systems of signification as well.

The three-dimensional analytical model might be helpful in analysing the multilayeredness of policy deliberations and should facilitate new empirical knowledge as to how such processes of deliberation take place in cases in which the rules of the game are uncertain and misunderstandings are abound. On the discourse dimension one would examine to what extent the practices are in fact about the development of discourse-coalitions held together by particular story lines that all important players can relate to. The dramaturgical dimension highlights the way in which governance is enacted. It suggests examining the development of trust and credibility under the difficult circumstances of multi-signification and institutional ambiguity in terms of performance and dramaturgy as well. Governance is then seen as much more than a matter of cognitive persuasion. It is about enacted social interaction and focuses on the practices that are able to produce such successes, this time highlighting the dramaturgical dimension instead of in terms of a cognitive and argumentative process of claims and counterclaims. That dramaturgy is a normal element of good policy making is, in my experience, immediately apparent to its reflective practitioners. The drafting of directives can show how administrators employ draft texts as generators of consensus by allowing everybody into the process and giving everybody a recognizable role. This is essentially a dramaturgy that is instrumental to the success as an ordinary string of meetings with the same people would not have been able to generate the same results (cf., for instance, Elgstrom, 2001). Finally, I suggested devoting the third analytical dimension to governance as deliberation, as it is likely that the practices of informal governance might actually be able to strengthen their own legitimacy and generate their own shared notion of orderly procedure.

Common standards for assessing the democratic legitimacy of representative institutions are not easily applicable to informal governance networks as they are found in the EU, which makes it tempting to judge these networks solely in terms of effectiveness and problem-solving capacity. This, however, would be a serious mistake - particularly in view of the legitimacy crisis that the EU faces now citizens in both France and the Netherlands have rejected the European constitution.

The debate conducted in the Netherlands during the months before the referendum provides an exemplary case of an unsuccessful dramaturgy; the script that was envisaged by the government failed as citizens rejected their role of passive, obedient audience. Dutch no-voters cited a variety of reasons for their choice, but a lack of information seemed to be the most important of these (European Commission, 2005). Apparently, the design process of the European constitution had remained opaque, notwithstanding its formal legitimation or the fact that drawing citizens into the European project was one of the primary aims of the European Convention. Practices of informal governance can be a threat to the openness of the EU policy processes, but formal procedures are no guarantee for inclusiveness either when they effectively cast citizens as an ignorant audience (cf., for instance, Young, 2002). In this respect, it would be a mistake to portray informal and formal governance as opposite ends of the 'legitimacy spectre'. 
Perhaps some are inclined to approach EU practices of informal governance as a temporary phenomenon that, over time, will give way to new, constitutionally embedded procedures. A reflection on the broader societal changes suggests otherwise (Hajer, 2003; Hajer \& Wagenaar, 2003). Our future might well be one in which temporary, informal arrangements take over the role of many tasks that we have come accustomed to see as the normal tasks of states and other standing governmental bodies.

This situation requires political-theoretical creativity. Standards must be developed to guarantee democratic legitimacy and accountability without hindering the adaptive, learning capacities of informal practices. This cannot be done without sound empirical knowledge. How do policy makers and politicians establish credibility when trust can not be assumed? How do they come to agree about the rules of the game? How do they define what really is at stake? Re-discovering governance as performance seems important to answer questions like these. The 3D-model allows the essential role of actor activity to be brought back into the analysis while appreciating the interaction with the conditions under which actors fulfil their roles. It thus provides conceptual tools to analyse the EU as not only a set of legal but also living institutions.

\section{Notes}

1 I have referred to this phenomenon as 'institutional void'. This term I derived from the world of art where it referred to a generation of post-modern artists that played with the 'modern' expectations of the audience (like in Jeff Koons with his work Ushering of Banality). Upsetting the expectations of various audiences they effectively exposed the discursive rules with which people approached the work of art, thus creating a new, and essentially open, basis for judging was beauty or quality was. A range of exhibitions employed the term 'void' to refer to this type of intervention. Judging from the responses, many people interpreted 'institutional void' as institutional 'emptiness'. This blurred the characteristic of different systems of meaning hitting upon each other. In light of the above I think the term 'institutional ambiguity' is better suited to bring out the meaning that I intended with the concept.

${ }^{2}$ Here culture refers to more than merely ethnic differences. After all, inter-cultural communication can also refer to debates between two distinct organizations, each with their own 'state of mind' (cf. Williams, 1981).

3 The notion was coined by Olsen (1998).

4 This requires detailed anthropological research into the EU informal governance networks, of which there are few examples (see for overviews Borneman \& Fowler, 1997; Verlot, 2001). Results of research already done suggest the relevance of this kind of analysis, as the rules for appropriate behaviour appear to be very strict. For instance, Trondal (2001, p. 17) quotes a Norwegian agency official attending the expert committees of the European Commission commenting that: 'It is important to participate in several meetings in order to learn the history of the group' (author's translation). 'The groups have certain codes of conduct. If some of these codes are violated, you are "dead" in the group' (Norwegian agency official - author's translation).

\section{References}

Austin, J. L. (1962) How To Do Things With Words? (Oxford, UK: Clarendon Press).

Benhabib, S. (Ed.) (1996) Democracy and Difference: Contesting the Boundaries of the Political (Princeton, NJ: Princeton University Press).

Bohman, J. (1996) Public Deliberation: Pluralism, Complexity, and Democracy (Cambridge, MA: MIT Press). Bohman, J. (1997) Deliberative Democracy: Essays on Reason and Politics (Cambridge, MA: MIT Press). Borneman, J., \& Fowler, N. (1997) Europeanization, Annual Review of Anthropology, 26, pp. $487-514$. 


\section{M. A. Hajer}

Edelman, M. (1964) The Symbolic Uses of Politics (Chicago: University of Illinois Press).

Egeberg, M., Schaefer, G. F., \& Trondal, J. (2003) The many faces of EU committee governance, West European Politics, 26(3), pp. 19-40.

Elgstrom, O. (2001) Norm negotiations: The construction of new norms regarding gender and development in EU foreign aid policy, Journal of European Public Policy, 7(3), pp. 457-476.

European Commission (2005, June) The European Constitution: Post-referendum Survey in the Netherlands, Flash Eurobarometer Report No. 172 (Directorate-General Press and Communication).

Everson, M., \& Joerges, C. (2000) Challenging the bureaucratic challenge, in: E. O. Eriksen \& J. E. Fossum (Eds) Democracy in the European Union: Integration Through Deliberation?, pp. 164-188 (London: Routledge).

Fischer, F. (1980) Politics, Values, and Public Policy: The Problem of Methodology (Boulder, CO: Westview Press).

Fischer, F. (2003) Reframing Public Policy: Discursive Politics and Deliberative Practices (Oxford, UK: Oxford University Press).

Fischer, F., \& Forester, J. (Eds) (1993) The Argumentative Turn in Policy Analysis and Planning (Durham, NC: Duke University Press).

Forester, J. (1999) The Deliberative Practitioner: Encouraging Participatory Planning Processes (Cambridge, MA: MIT Press)

Gagliardi, P. (1990) Symbols and Artifacts: Views of the Corporate Landscape (Berlin: Walter de Gruyter). Geertz, C. (1980) Negara: The Theatre State in Nineteenth-century Bali (Princeton, NJ: Princeton University Press).

Goodsell, C. T. (1988) The Social Meaning of Civic Space: Studying Political Authority Through Architecture (Lawrence, KS: University Press of Kansas).

Gutmann, A., \& Thompson, D. (1996) Democracy and Disagreement (Cambridge, MA: Belknap Press).

Hajer, M. A. (1995) The Politics of Environmental Discourse: Ecological Modernization and the Policy Process (Oxford, UK: Oxford University Press).

Hajer, M. A. (2003) Policy without polity? Policy analysis and the institutional void, Policy Sciences, 36(2), pp. $175-195$.

Hajer, M. A. (2005) Setting the stage: A dramaturgy of policy making, Administration and Society, 36(6), pp. $624-647$.

Hajer, M. A., \& Laws, D. (2006) Ordering through Discourse, in: M. Moran, M. Rein \& R. E. Goodin (Eds) The Oxford Handbook of Public Policy, pp. 251-268 (Oxford: Oxford University Press).

Hajer, M. A., \& Wagenaar, H. (Eds) (2003) Deliberative Policy Analysis: Understanding Governance in the Network Society (Cambridge, UK: Cambridge University Press).

Hariman, R. (1995) Political Style: The Artistry of Power (Chicago: University of Chicago Press).

Harré, R., \& Gillett, G. (1994) The Discursive Mind (Thousand Oaks, CA: Sage).

Hilgartner, S. (2001) Science on Stage (Stanford, CA: Stanford University Press).

Howarth, D., \& Torfing J. (Eds) (2004) Discourse Theory and European Politics: Identity, Policy and Governance (London: Palgrave).

Jasanoff, S. (1990) The Fifth Branch: Science Advisers as Policy Makers (Cambridge, MA: Harvard University Press).

Jensen, O. B., \& Richardson, T. (2004) Making European Space: Mobility, Power and Territorial Identity (London: Routledge).

Latour, B. (1987) Science in Action (Cambridge, MA: Harvard University Press).

Latour, B. (1994) Pasteur: une science, un style, un siècle (Paris: Perrin).

Laws, D. (2001) Enacting deliberation: Speech and the micro-foundations of deliberative democracy. Paper presented in Workshop 9 at the EPCR Joint Sessions, Grenoble, France.

Lynch, M. (1991) Laboratory space and the technological complex: An investigation of topical contextures, Science in Context, 4(1), pp. 51-78.

Mak, J., \& van Tatenhove, J. (2006) Introduction: Informality in a future EU, Perspectives on European Politics and Society, 7(1), pp. 1-7.

Olsen, J. P. (1998, 20-22 September) The new European experiment in political organization. Paper presented at the Samples of the Future conference, SCANCOR, Stanford University, Stanford, CA.

Olsen, J. P. (2000) Organising European institutions of governance: A prelude to an institutional account of political integration. Arena Working Paper No. 00/2. Available at http://www.arena.uio.no/ publications/wp00_2.htm\#*_opp (accessed 5th December 2005). 
Porter, T. M. (1995) Trust in Numbers: The Pursuit of Objectivity in Science and Public Life (Princeton, NJ: Princeton University Press).

Rittberger, B. (2001) Which institutions for post-war Europe? Explaining the institutional design of Europe's first community, Journal of European Public Policy, 8(5), pp. 673-708.

Roe, E. (1994) Narrative Policy Analysis: Theory and Practice (Durham, NC: Duke University Press).

Schechner, R. (1988) Performance Theory (New York: Routledge).

Schechner, R. (1993) The Future of Ritual: Writings on Culture and Performance (London: Routledge).

Schmidt, V. A. (2002) The Futures of European Capitalism (Oxford, UK: Oxford University Press).

Schön, D. A., \& Rein, M. (1994) Frame Reflection: Toward the Resolution of Intractable Policy Controversies (New York: Basic Books).

Szerszynski, B., Heim, W., \& Waterton, C. (2003) Nature Performed: Environment, Culture and Performance (Oxford, UK: Blackwell).

Torgerson, D. (2002, October) Policy as performance. Paper presented at the workshop on changing forms of governance and deliberative democracy, at the conference of the Netherlands Institute of Government, Rotterdam, The Netherlands.

Trondal, J. (2001) Is there any social constructivist - institutionalist divide? Unpacking social mechanisms affecting representational roles among EU decision-makers, Journal of European Public Policy, 8(1), pp. $1-23$.

Trondal, J., \& Veggeland, F. (2003) Access, voice and loyalty; the representation of domestic civil servants in EU committees, Journal of European Public Policy, 10(1), pp. 59- 77.

Verlot, M. (2001) Are politicians human? Problems and challenges of institutional anthropology, Social Anthropology, 9(3), pp. 345-353.

Walters, W., \& Haahr, J. H. (2005) Governing Europe: Discourse, Governmentality and European Integration (New York: Routledge).

Waterton, C. (2003) Performing the classification of nature, in: B. Szerszynski, W. Heim \& C. Waterton (Eds) Nature Performed: Environment, Culture and Performance, pp. 111-129 (Oxford, UK: Blackwell).

Wenger, E. (1998) Communities of Practice: Learning, Meaning, and Identity (Cambridge, UK: Cambridge University Press).

Wessels, W. (1998) Comitology: Fusion in action - Politico-administrative trends in the EU system, Journal of European Public Policy, 5(2), pp. 209-234.

White, J. D. (1999) Taking Language Seriously: The Narrative Foundations of Public Administration Research (Washington, DC: Georgetown University Press).

Williams, R. (1981) Culture (London: Fontana).

Yanow, D. (1995) Practices of policy interpretation, Policy Sciences, 28(2), pp. 111- 126.

Yanow, D. (1996) How Does a Policy Mean? Interpreting Policy and Organizational Actions (Washington, DC: Georgetown University Press).

Young, I. M. (2002) Inclusion and Democracy (Oxford, UK Oxford University Press). 